Вісник Харківського національного університету імені В.Н. Каразіна Серія "Математика, прикладна математика і механіка" Том 91, 2020, c. 4-20

УДК 517.9
Visnyk of V.N.Karazin Kharkiv National University Ser. "Mathematics, Applied Mathematics and Mechanics"

Vol. 91, 2020, p. 4-20

DOI: $10.26565 / 2221-5646-2020-91-01$

\title{
Korobov's controllability function method applied to finite-time stabilization of the Rössler system via bounded controls
}

Abdon E. Choque-Rivero ${ }^{1}$, Graciela A. González ${ }^{2,3}$, Efrain Cruz Mullisaca ${ }^{4}$

${ }^{1}$ Instituto de Física y Matemáticas, Universidad Michoacana de San Nicolás de Hidalgo, Edificio C-3, C.U., CP 58060, Morelia, Mich., México

2 Universidad de Buenos Aires, Facultad de Ingeniería, Departamento de Matemática, Buenos Aires, Argentina

3 Consejo Nacional de Investigaciones Cientificas y Técnicas, CONICET, Buenos Aires, Argentina

${ }^{4}$ Carrera de Matemática, Facultad Ciencias Puras y Naturales, Universidad Mayor de San Andrés, Monoblock Central, CP 15000, La Paz, Bolivia abdon.choque@umich.mx,ggonzal@fi.uba.ar, ecruz3@umsa.bo

The problem of stabilizing the Rössler system in finite time by bounded control is considered. We employ V. I. Korobov's controllability function method, which involves a Lyapunov-type function. The controllability function is the solution of an implicit equation. A family of bounded controls which solve the problem is explicitly computed. Besides, the time that it takes the trajectory to reach the desired equilibrium is estimated.

Keywords: Rössler system; Korobov's controllability function; bounded control; finite time stabilization.

Чоке-Ріверо А. Е., Гонзалес Грасіела А., Круз Муллісака Е. Метод функції керованості Коробова, застосований до стабілізації системи Росслера за обмежений час за допомогою обмежених керувань. Розглянуто задачу стабілізації системи Росслера за скінченний час за допомогою обмежених керувань. Ми застосовуємо метод функції керованості В. І. Коробова, який використовує функцію типу Ляпунова. Функція керованості є розв'язком неявного рівняння. Запропоновано сім'ю явно обчислюваних обмежених керувань, які розв'язують задачу синтезу. Окрім того, оцінюється час руху, потрібний для досягнення точки рівноваги.

Ключові слова: Система Росслера; функція керованості Коробова; обмежене керування; стабілізація за скінченний час.

Чоке-Риверо А. Э., Гонзалес Грасиела А., Круз Муллисака Э. Подход функции упраляемости Коробова приложенный к стабилизации системы Росслера за конечное время с помощью ограниченных управлений. Рассматривается задача стабилизации системы Росслера за конечное время при ограниченном управлении. Используем метод функций управляемости В. И. Коробова, являющийся функцией типа Ляпунова. Функция управляемости является решением неявного уравнения. Предлагается семейство явно вычисляемых ограниченных управлений, которые решают задачу синтеза. Кроме того, оценивается время движения, необходимое для достижения точки покоя.

(C) A. E. Choque-Rivero, Graciela A. González, E. Cruz Mullisaca, 2020 
Ключевые слова: Система Росслера; функция упраляемости Коробова; ограниченное управление; стабилизации за конечное время.

2010 Mathematics Subject Classification: 93C15; 93B05; 34D20

\section{Introduction}

Rössler system has become one of the reference chaotic systems. Its novelty when introduced in [25], being that exhibits a chaotic attractor generated by a simpler set of nonlinear differential equations than Lorenz system. It is given by:

$$
\begin{aligned}
& \dot{x}_{1}=-x_{2}-x_{3}, \\
& \dot{x}_{2}=x_{1}+\alpha x_{2}, \\
& \dot{x}_{3}=\beta+x_{3}\left(x_{1}-\gamma\right),
\end{aligned}
$$

and it develops chaotic behaviour for certain values of the parameter triplet $(\alpha, \beta, \gamma)$. The issue of controlling Rössler system by stabilizing one of its unstable equilibrium points has been previously dealt with in the literature. A feedback controller is designed in [12] stabilizing a chosen equilibrium point with exponential convergence and estimating the negative Lyapunov exponent. In [2], a sliding mode control is proposed by which global stabilization of an arbitrary given equilibrium point is achieved, In [23], an optimal control strategy that directs the chaotic motion to any desired equilibrium point is proposed. Both stability and optimality are obtained in [24] by applying linear feedback controllers to the chaotic Rössler system. A suboptimal feedback controller has been tested on the Rössler system in [27]. The synchronization approach and bifurcation diagram have been used in [18] to control the Rössler system. In this work, control of the Rössler system is stated by putting:

$$
\begin{aligned}
& \dot{x}_{1}=-x_{2}-x_{3}, \\
& \dot{x}_{2}=x_{1}+\alpha x_{2}, \\
& \dot{x}_{3}=\beta+x_{3}\left(x_{1}-\gamma\right)+u,
\end{aligned}
$$

and considering the synthesis problem. Let $x=\left(x_{1}, x_{2}, x_{3}\right)^{\top}$. The synthesis problem consists in constructing a positional control $u=u(x)$ with $|u(x)| \leq u_{1}$ such that for any $x^{0}$ belonging to a certain neighborhood of the equilibrium point of the system (1), the trajectory $x(t)$ initiated in $x^{0}$ arrives at this equilibrium point in finite time. Namely, by using V. I. Korobov's method, also called the controllability function method, a family of bounded positional controls that solve the synthesis problem for the Rössler system is proposed. We mainly use two ingredients. The first one concerns the general theory of the controllability function [14]. The second ingredient is the family of bounded positional controls that was obtained in [7]. Note that the finite-time stabilization of control systems was studied in [8], [5], [6], [19], [20] and references therein. Different from previous works on finite-time stabilization [20], [21], we propose an explicit family of 
bounded controls constructed by taking into account the only nonlinearity of the Rössler system, which is a quadratic function.

\section{Dynamical features of the Rössler system}

The equilibrium point of the system (1) for the triplet $(0, \beta, \gamma)$ with $\gamma \neq 0$ is $\bar{x}:=\left(0,-\frac{\beta}{\gamma}, \frac{\beta}{\gamma}\right)^{\top}$. For the triplet $(\alpha, \beta, \gamma)$ with $\alpha \neq 0$ and $\gamma^{2}-4 \alpha \beta=0$, there is only one equilibrium point: $\bar{x}:=\left(\frac{\gamma}{2},-\frac{\gamma}{2 \alpha}, \frac{\gamma}{2 \alpha}\right)^{\top}$. While if $\gamma^{2}-4 \alpha \beta>0$, there are two equilibrium points:

$$
\bar{x}_{ \pm}:=\left(\frac{\gamma \pm \Delta}{2},-\frac{\gamma \pm \Delta}{2 \alpha}, \frac{\gamma \pm \Delta}{2 \alpha}\right)^{\top},
$$

where $\Delta:=\sqrt{\gamma^{2}-4 \alpha \beta}$. For any other case, system (1) has no equilibrium point. The typical chaotic Rössler system is determined by $\alpha=\beta=\frac{1}{5}$ and $\gamma=\frac{57}{10}$, resulting: $\quad \bar{x}_{-}=\left(\frac{1}{20}(57-\sqrt{3233}), \frac{1}{4}(\sqrt{3233}-57), \frac{1}{4}(57-\sqrt{3233})\right)$ and $\bar{x}_{+}=\left(\frac{1}{20}(57+\sqrt{3233}), \frac{1}{4}(-57-\sqrt{3233}), \frac{1}{4}(57+\sqrt{3233})\right)$.

The stability exponents of $\bar{x}_{-}$are $\{-5.686,0.0970 \pm i 0.9951\}$ so it is a saddle-focus with a two-dimensional unstable manifold. Besides, this point is placed in the nearness of the attractor. Instead, the stability exponents of $\bar{x}_{+}$ are $\left\{0.1929,-4.596 \times 10^{-6} \pm i 5.428\right\}$. Hence, this equilibrium point has a twodimensional stable manifold but it is outside the region of the chaotic attractor. For details, see [1], [22] or [10], where information about dynamical behavior of this system for other parameter values is provided.

\section{Canonical controllable form}

Let us consider the case $\alpha \neq 0$. Introducing $y=x-\bar{x}_{ \pm}$, system (2) takes the following form:

$$
\dot{y}=A_{ \pm} y+\left(\begin{array}{c}
0 \\
0 \\
y_{1} y_{3}
\end{array}\right)+b u,
$$

being $y:=\left(y_{1}, y_{2}, y_{3}\right)^{\top}, b:=(0,0,1)^{\top}$ and

$$
A_{ \pm}:=\left(\begin{array}{ccc}
0 & -1 & -1 \\
1 & \alpha & 0 \\
\frac{\gamma \pm \Delta}{2 a} & 0 & -\frac{\gamma \mp \Delta}{2}
\end{array}\right)
$$

Let us note that the linear part of (4) results a completely controllable system. Then, there exists a coordinate change to transform it into its canonical controllable form [11], [13]. This coordinates change is given by $z=F y$ with

$$
F:=\left(\begin{array}{ccc}
0 & -1 & 0 \\
-1 & -\alpha & 0 \\
-\alpha & 1-\alpha^{2} & 1
\end{array}\right),
$$


and system (4) can be rewritten as follows:

$$
\dot{z}=A_{0} z+b p_{ \pm}^{\top} z+b u+\left(\begin{array}{c}
0 \\
0 \\
\left(\alpha z_{1}-z_{2}\right)\left(z_{1}-\alpha z_{2}+z_{3}\right)
\end{array}\right)
$$

being $z:=\left(z_{1}, z_{2}, z_{3}\right)^{\top}$. Here

$$
A_{0}:=\left(\begin{array}{ccc}
0 & 1 & 0 \\
0 & 0 & 1 \\
0 & 0 & 0
\end{array}\right)
$$

and

$$
p_{ \pm}:=\left(\begin{array}{c} 
\pm \Delta \\
\frac{(\gamma \mp \Delta) \alpha^{2}-2 \alpha-\gamma \mp \Delta}{2 \alpha} \\
\alpha-\frac{\gamma}{2} \pm \frac{\Delta}{2}
\end{array}\right) .
$$

Remark 1.1. For the case $\alpha=0$, the matrix (5) is given by

$$
\left(\begin{array}{ccc}
0 & -1 & -1 \\
1 & 0 & 0 \\
\frac{\beta}{\gamma} & 0 & -\gamma
\end{array}\right)
$$

The matrix $F$ of the transformation $z=F y$ is equal to $\left(\begin{array}{ccc}0 & -1 & 0 \\ -1 & 0 & 0 \\ 0 & 1 & 1\end{array}\right)$. The nonlinear part of ( 7$)$ is given by $\left(\begin{array}{c}0 \\ 0 \\ -z_{2}\left(z_{1}+z_{3}\right)\end{array}\right)$ and the vector (9) can be written as $\left(-\gamma,-\frac{\beta}{\gamma}-1,-\gamma\right)^{\top}$.

\section{The controllability function method}

Consider the canonical 3-dimensional control system

$$
\dot{z}=f(z, u), z \in \mathbb{R}^{n}, u \in \Omega \subset \mathbb{R}
$$

where $\Omega$ is a closed interval of $\mathbb{R}$.

Considering the synthesis problem for the system (10), in 1979, V. I. Korobov [14] created the controllability function $(\mathrm{CF}) \theta(x)$. The CF is a Lyapunov-type function, i.e., $\theta(x)>0$ for $x \neq 0$ and $\theta(0)=0$. The CF satisfies the following inequality:

$$
\sum_{i=1}^{n} \frac{\partial \theta(z)}{\partial z_{i}} f_{i}(z, u(z)) \leq-\varphi(\theta(z))
$$


where $\varphi(\theta)>0$ for $\theta \neq 0, \varphi(0)=0$ and

$$
\int_{0}^{\bar{\theta}} \frac{d \theta}{\varphi(\theta)}<\infty, \quad \bar{\theta}>0 .
$$

Let us consider the canonical control system

$$
\dot{z}=A_{0} z+b w, \quad|w| \leq w_{1},
$$

where $A_{0}$ is given in Equation (8). Following [7], a family of bounded positional controls $w(z)$ that stabilize the system (13) at finite time can be constructed. In particular, the value of the $\mathrm{CF}$ at the given initial position $z^{0}$ is exactly $T\left(z^{0}\right)$ the time that the trajectory from $z^{0}$ takes to arrive at the origin. As in previous works of V. I. Korobov and coauthors [15], [16], [17], the CF $\theta(z)$ is proposed in [7] as the solution of the following implicit equation

$$
2 a_{0} \theta=(K(\theta) z, z) .
$$

Here $(\cdot, \cdot)$ is the canonical inner product while $a_{0}$ is a positive number to be determined and $K(\theta)$ is a $3 \times 3$ positive definite matrix for $\theta>0$ defined as $K(\theta):=D(\theta) K_{1} D(\theta)$ where

$$
D(\theta):=\left(\begin{array}{ccc}
\theta^{-\frac{5}{2}} & 0 & 0 \\
0 & \theta^{-\frac{3}{2}} & 0 \\
0 & 0 & \theta^{-\frac{1}{2}}
\end{array}\right),
$$

and

$$
K_{1}:=\left(\begin{array}{ccc}
\frac{40 a_{1}}{a_{1}+30} & -\frac{240-12 a_{1}}{a_{1}+30} & -\frac{120}{a_{1}+30} \\
-\frac{240-12 a_{1}}{a_{1}+30} & -\frac{180-4 a_{1}}{a_{1}+30} & -\frac{60}{a_{1}+30} \\
-\frac{120}{a_{1}+30} & -\frac{60}{a_{1}+30} & -\frac{12}{a_{1}+30}
\end{array}\right),
$$

for

$$
a_{1}<-40 .
$$

Furthermore,

$$
\begin{aligned}
& \frac{1}{\theta} K-\frac{d}{d \theta} K=\frac{1}{\theta} D(\theta) K_{2} D(\theta), \\
& K_{2}:=\left(\begin{array}{ccc}
\frac{240 a_{1}}{a_{1}+30} & -\frac{5\left(240-12 a_{1}\right)}{a_{1}+30} & -\frac{480}{a_{1}+30} \\
-\frac{5\left(240-12 a_{1}\right)}{a_{1}+30} & -\frac{4\left(180-4 a_{1}\right)}{a_{1}+30} & -\frac{180}{a_{1}+30} \\
-\frac{480}{a_{1}+30} & -\frac{180}{a_{1}+30} & -\frac{24}{a_{1}+30}
\end{array}\right)
\end{aligned}
$$

and

$$
2 a_{0} \leq \frac{36}{a_{1}^{2}+12 a_{1}+360} w_{1}^{2} .
$$


The bounded positional control $w(z)$ that solves the synthesis problem for the system (13) is given by

$$
w(z)=a^{\top}(\theta(z)) z
$$

where

$$
a(\theta):=\left(\begin{array}{c}
\frac{a_{1}}{\theta^{3}} \\
\left(\frac{a_{1}}{3}-10\right) \frac{1}{\theta^{2}} \\
-\frac{6}{\theta}
\end{array}\right)
$$

and $\theta(z)$ is the solution of the implicit equation (14).

The fact that the value $\theta\left(z^{0}\right)$ coincides with $T\left(z^{0}\right)$ is guaranteed by the equality

$$
\dot{\theta}=-1,
$$

which in turn is a special case of the inequality (11).

In terms of the matrices $A_{0}, K=K(\theta)$, the vector $b$ and $a=a(\theta)$, Equality $(21)$ is equivalent to the following matrix equation

$$
K A_{0}+A_{0}^{\top} K+a b^{\top} K+K b a^{\top}+\frac{1}{\theta} K-\frac{d}{d \theta} K=0_{3} .
$$

Here $0_{3}$ is the $3 \times 3$ null matrix.

\section{The CF for nonlinear control systems}

The controllability function method for nonlinear control systems with non controllable linear part was considered in [3], [4]. In the case when the linear part of the nonlinear control system is completely controllable, the general solution of the synthesis problem was proposed by V. I. Korobov in [14]. This is the case for the controlled Rössler system (2), so, we develop for it a rather specific family of bounded controls based on the control (19). We also focus on the specific form of the nonlinear part of the control system (2).

Note that the nonlinear part of the translated system (4)

$$
g(y):=\left(0,0, y_{1} y_{3}\right)^{\top}
$$

is a Lipschitz function in a neighborhood of the origin; consequently, a positive number $C_{1}$ exists such that

$$
\|g(y)\| \leq C_{1}\|y\| \text {. }
$$

Let us introduce the positional control given by

$$
u=w-p^{\top} z,
$$

where $w$ is defined as in (19). To deal with the linear control part of the system (7) as if it were the canonical control system (13), we look for the restriction on control $w$. Here we use the same idea as in [14]. We set

$$
w_{1}:=u_{1}-u_{2} \sum_{j=1}^{3}\left|p_{j}\right| .
$$


We assume that $u_{2}<\frac{u_{1}}{\sum_{j=1}^{3}\left|p_{j}\right|}$. As in [14], we require that the system (7) is considered in the neighborhood

$$
Q:=\left\{z:\left|z_{j}\right| \leq u_{2}, \quad j=1,2,3\right\} .
$$

Note that the linear part of the system (2) at equilibrium points described in Section 2 is completely controllable.

In the following result, we calculate the time derivative of the $\mathrm{CF} \theta$ with respect to the system (7). Our goal is to verify the inequality (11) for some function $\varphi$.

Notation. Let $S$ be an $n \times n$ matrix. The norm of $S$ is defined by

$$
\|S\|:=\max _{1 \leq j \leq n} \sum_{i=1}^{m}\left|s_{i j}\right| .
$$

The number $\lambda_{\min , S}$ is the smallest eigenvalue of matrix $S$. Here we suppose that $S$ is a symmetric matrix.

Theorem 1. Let $K_{1}, K_{2}$ and $C_{1}$ be as in (15), (17) and (22). The following inequality is valid:

$$
\dot{\theta} \leq-1+2 \theta \frac{C_{1}\left\|K_{1}\right\|}{\lambda_{\min , K_{2}}} .
$$

Proof. By taking the derivative of the equality (14) with respect to time $t$ and the system (7), we have

$$
\begin{aligned}
\dot{\theta} & =\frac{\left(\left(K A_{0}+A_{0}^{\top} K+a b^{\top} K+K b a^{\top}\right) z, z\right)}{\left(\left(\frac{1}{\theta} K-\frac{d}{d \theta} K\right) z, z\right)}+2 \frac{\left(K z, F g\left(F^{-1} z\right)\right)}{\left(\left(\frac{1}{\theta} K-\frac{d}{d \theta} K\right) z, z\right)} \\
& =-1+2 \frac{\left(K z, F g\left(F^{-1} z\right)\right)}{\left(\left(\frac{1}{\theta} K-\frac{d}{d \theta} K\right) z, z\right)} \\
& \leq-1+2 \theta \frac{C_{1}\left\|K_{1}\right\|}{\lambda_{\min , K_{2}}} .
\end{aligned}
$$

In the last inequality, we used the obvious inequality

$$
\frac{\left(K z, F g\left(F^{-1} z\right)\right)}{\left(\left(\frac{1}{\theta} K-\frac{d}{d \theta} K\right) z, z\right)} \leq \theta \frac{C_{1}\left\|K_{1}\right\|}{\lambda_{\min , K_{2}}} .
$$

Note that inequality (12) is satisfied if $\varphi(\theta)=1-M \theta$, for some positive $M$ :

$$
\int_{0}^{\bar{\theta}} \frac{1}{1-M \theta} d \theta=-\frac{1}{M} \ln (1-M \bar{\theta}), \quad 1 \geq \bar{\theta} M .
$$

By employing inequality (26), the following remark yields. A similar remark appeared in [9]. 
Remark 1.2. Let $\widehat{\theta}>0, C_{2}>0$ such that for $\theta \leq \widehat{\theta}$

$$
-1+\theta \frac{C_{1}\left\|K_{1}\right\|}{\lambda_{\min , K_{2}}} \leq-C_{2} .
$$

Then, the following inequality is valid:

$$
\dot{\theta} \leq-C_{2} \text {. }
$$

And the next bound on the arriving time is obtained

$$
T(z) \leq \frac{\theta_{0}}{C_{2}}
$$

Proof. In view of (26), the inequality (29) readily follows. To prove (30), we integrate (29) on the trajectory $z=z(t)$. We attain $\theta(z(t))-\theta_{0} \leq-C_{2} t$. By employing [14, page 552], we have that $z(T)=0$. This implies $\theta(z(T))=0$; thus we obtain inequality (30).

Remark 1.3. The following optimization problem will be useful for improving the size of the neighborhood of the origin where initial conditions must be chosen to achieve the control objective:

$$
\max _{\theta>0} \chi(z, \theta)
$$

for $\|z\| \leq C$ and such that $\chi<0$, where

$$
\chi(z, \theta):=-1+2 \frac{\left(K z, F g\left(F^{-1} z\right)\right)}{\left(\left(\frac{1}{\theta} K-\frac{d}{d \theta} K\right) z, z\right)} .
$$

Let $\widehat{\theta}$ be the value at which the maximum of $\chi$ is achieved. This value of $\widehat{\theta}$ can be employed instead of $\hat{\theta}$ of Remark 1.2. On the other hand, for applications, available software should be more adequate.

The existence of such $\widehat{\theta}$ is verified by Remark 1.2. The proof of this remark can be carried out by using the Lagrange multipliers.

Remark 1.4. Considering the control system (10), in the case when the origin is an equilibrium point of (10), according to [14, Theorem 1], the state variables $z_{k}(t)$, for $k=1,2,3$ do not leave a certain neighborhood of the origin and approach the equilibrium point as $t \rightarrow T$. For $t>T$ the trajectory $z(t)$ stays at the equilibrium point. Both these phenomena are explained by the fact that the control is a positional control that stabilizes the system at finite time.

Lemma 1. Let $\overline{\bar{x}}$ be one of the equilibrium points described in Section 2. Let $a:=\left(a_{1},\left(\frac{a_{1}}{3}-10\right),-6\right)^{\top}$, with $a_{1}<-40$. Furthermore, let $\left(k_{j, \ell}\right)_{j, \ell=1}^{3}:=K_{1}$, and let the parameter $a_{0}$ satisfy (18). Thus, $\theta(x-\overline{\bar{x}})$ is the unique positive solution of

$$
\mathcal{E}(x, \theta, \overline{\bar{x}})=0
$$


with

$$
\mathcal{E}(x, \theta, \overline{\bar{x}}):=2 a_{0} \theta^{6}-\sum_{j, \ell=1}^{3} k_{j, \ell} \theta^{j+\ell-2}\left(c, A^{j-1}(x-\overline{\bar{x}})\right)\left(c, A^{\ell-1}(x-\overline{\bar{x}})\right),
$$

where vector $c$ is such that $(b, c)=0,(A b, c)=0$ and $\left(A^{2} b, c\right)=1$.

The proof of this lemma repeats the proof of the first part of [14, page 540].

Remark 1.5. Fixed $\theta$, the set $E:=\left\{x \in \mathbb{R}^{3}: \mathcal{E}(x, \theta, \overline{\bar{x}})=0\right\}$ is an ellipsoid. The trajectories of the system (2) starting from the volume embraced by $E$ or on $E$ do not escape from this set. For $t \rightarrow T$ the trajectory of the system approaches the equilibrium point $\overline{\bar{x}}$.

Let $Q_{1}$ be the domain in $\mathbb{R}^{3}$ that corresponds to (25), i.e., after the transformation $y=F^{-1} z$ and the translation $y=x-\overline{\bar{x}}$, that is, $Q_{1}:=\left\{x \in \mathbb{R}^{3}: x=\right.$ $\left.F^{-1} z+\overline{\bar{x}}, \quad z \in Q\right\}$. Define

$$
Q_{2}:=\left\{x \in \mathbb{R}^{3} \mid \theta(x-\overline{\bar{x}})<\widetilde{\theta}\right\}
$$

where $\widetilde{\theta} \leq \widehat{\theta}$ and such that $Q_{2} \subset Q_{1}$. The main result of our work is seen below.

Theorem 2. Let $p$ be defined as in (9). Under the conditions of Lemma 1, let

$$
u(x, \overline{\bar{x}})=\sum_{j=1}^{3} a_{j}\left(\theta^{j-3}(x-\overline{\bar{x}})\right)\left(c, A^{j-1}(x-\overline{\bar{x}})\right)-\sum_{j=1}^{3} p_{j}(x-\overline{\bar{x}})\left(c, A^{j-1}(x-\overline{\bar{x}})\right) .
$$

Suppose that $x^{0}=\left(x_{1}^{0}, x_{2}^{0}, x_{3}^{0}\right)$ belongs to $Q_{2}$.

Thus, a) the control (34) satisfies the condition $|u(x)| \leq u_{1}$ and solves the synthesis problem. b) The time taken by the trajectory from $x^{0}$ to the equilibrium point $\overline{\bar{x}}$ satisfies the following inequality:

$$
T\left(x^{0}, \overline{\bar{x}}\right) \leq \frac{\theta_{0}}{C_{2}} .
$$

Proof. Part a) is proven by employing (13), (23) and (25). Part b) readily follows from (30), the transformation $z=F y$ and the translation $y=x-\overline{\bar{x}}$. Recall that $u_{1}$ is a number that indicates the boundaries of the control set.

Remark 1.6. The parameter $a_{1}$ determines the vector (20). For each $a_{1}<-40, a$ positional control which solves the synthesis problem is computed by (34). Besides, both the neighborhood $Q_{2}$ where the initial conditions must be taken to achieve control objective and an upper bound of the time to reach the equilibrium, are also obtained (formulae (33) and (35), respectively).

Remark 1.7. The value $\widehat{\theta}$ as introduced in Remark 1.4, involves to solve on optimization problem but it provides a better optimization of $Q_{2}$ than if the value $\widehat{\theta}$ of Remark 1.6 is applied. 


\section{Graph of the trajectory and control}

For a given initial point $\left(x_{1}^{0}, x_{2}^{0}, x_{3}^{0}\right)$, to plot the graph of the trajectory $x(t)$, the differential equation (27) is extended as follows:

$$
\begin{aligned}
\dot{x}_{1} & =-x_{2}-x_{3}, \\
\dot{x}_{2} & =x_{1}+\alpha x_{2}, \\
\dot{x}_{3} & =\beta+x_{3}\left(x_{1}-\gamma\right)+u(x, \theta, \overline{\bar{x}}), \\
\dot{\theta} & =-1+2 \psi(x, \theta, \overline{\bar{x}})
\end{aligned}
$$

with initial conditions $x_{1}(0)=x_{1}^{0}, x_{2}(0)=x_{2}^{0}, x_{3}(0)=x_{3}^{0}$ and $\theta(0)=\theta_{0}$. Here $\theta_{0}$ is the root equation (31), and

$$
\psi(x, \theta, \overline{\bar{x}}):=\frac{\left(D(\theta) K_{1} D(\theta)(x-\overline{\bar{x}}), F g\left(F^{-1}(x-\overline{\bar{x}})\right)\right)}{\frac{1}{\theta}\left(D(\theta) K_{2} D(\theta)(x-\overline{\bar{x}}),(x-\overline{\bar{x}})\right)}
$$

with $\theta=\theta(x-\overline{\bar{x}})$.

Example 1. For $\alpha=\beta=0.2$ and $\gamma=5.7$, we have the Rössler chaotic system and $\bar{x}_{+}=(5.69297,-28.4649,28.4649)$ is one of the corresponding equilibrium points. Let $u_{1}=3.2$ and let $a_{1}=-45$. The positional control has the form $u(x)=-\frac{6\left(0.2\left(5.69297-x_{1}\right)+0.96\left(x_{2}+28.4649\right)+x_{3}-28.4649\right)}{\theta}+\frac{45\left(x_{2}+28.4649\right)}{\theta^{3}}-\frac{-25 x_{1}-5 x_{2}}{\theta^{2}}-$ $29.4249 x_{1}-0.392 x_{2}-0.192974 x_{3}+161.85$. The graphs of $x_{1}(t)-\bar{x}_{+}^{1}, x_{2}(t)-\bar{x}_{+}^{2}$ and $x_{3}(t)-\bar{x}_{+}^{3}$ are shown in Fig. 1.

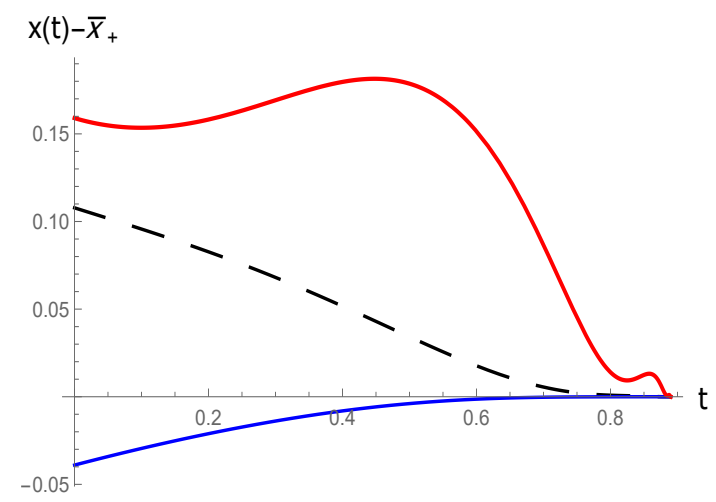

Fig. 1. Trajectories of $x_{1}(t)-\bar{x}_{+}^{1}, x_{2}(t)-\bar{x}_{+}^{2}$ and $x_{3}(t)-\bar{x}_{+}^{3}$.

The graph of the position control $u(x(t))$ is displayed in Fig. 2 .

The controllability function on the trajectory $\theta(x(t)$ is shown in Fig. 3 . 


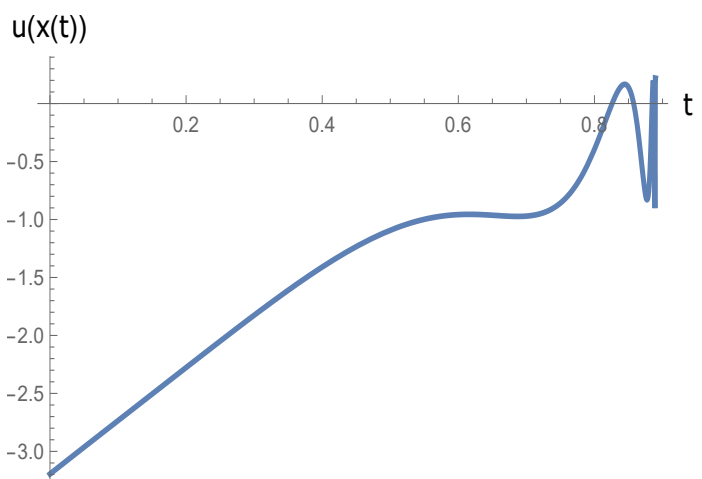

Fig. 2. The positional control $u(x(t))$.

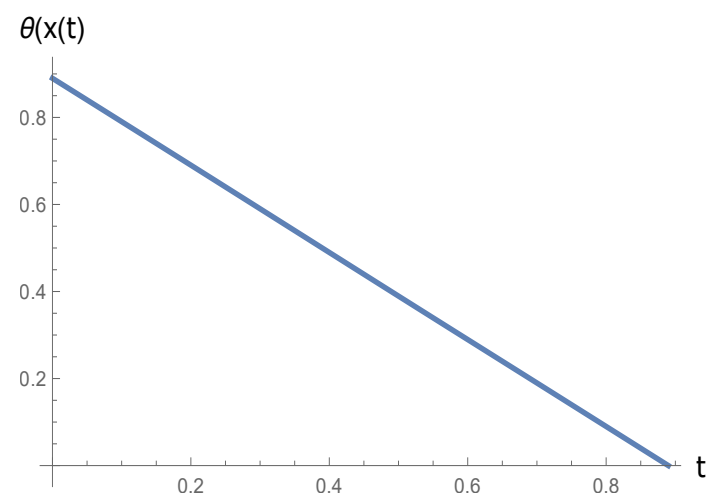

Fig. 3. The controllability function $\theta(x(t))$.

By using Wolfram Mathematica, we have calculated that the time of arriving from $x^{0}=(5.80077379,-28.5038689,28.6238689)$ to the equilibrium point $\bar{x}_{+}$is $T\left(x^{0}, \bar{x}_{+}\right)=0.8898539650858471$ and that $\left|x_{1}(T)-5.69297\right| \leq 1.05197 * 10^{-9}$, $x_{2}(T)=-28.4649$ and $\left|x_{3}(T)-28.6238689\right| \leq 1.177185658 * 10^{-5}$.

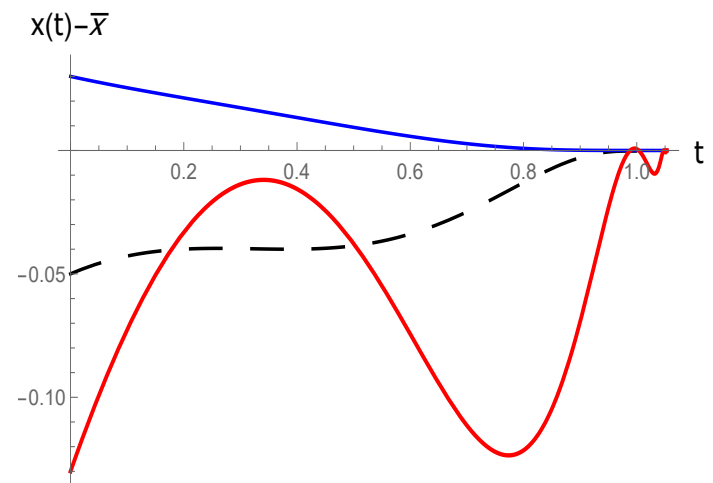

Fig. 4. Trajectories of $x_{1}(t)-\bar{x}^{1}, x_{2}(t)-\bar{x}^{3}$ and $x_{3}(t)-\bar{x}^{3}$. 
Example 2. Let $\alpha=0, \beta=1 / 5$ and $\gamma=1$. The corresponding equilibrium point is equal to $\bar{x}=\left(0,-\frac{1}{5}, \frac{1}{5}\right)$. Let $u_{1}=1.1$ and let $a_{1}=-45$. The positional control has the form $u(x)=\frac{45\left(x_{2}+\frac{1}{5}\right)}{\theta^{3}}+\frac{25 x_{1}}{\theta^{2}}-\frac{6\left(x_{2}+x_{3}\right)}{\theta}-\frac{6 x_{1}}{5}+x_{3}-\frac{1}{5}$. The graphs of $x_{1}(t)-\bar{x}^{1}, x_{2}(t)-\bar{x}^{3}$ and $x_{3}(t)-\bar{x}^{3}$ are shown in Fig. 4 .

The graph of the position control $u(x(t))$ is seen in Fig. 5 .

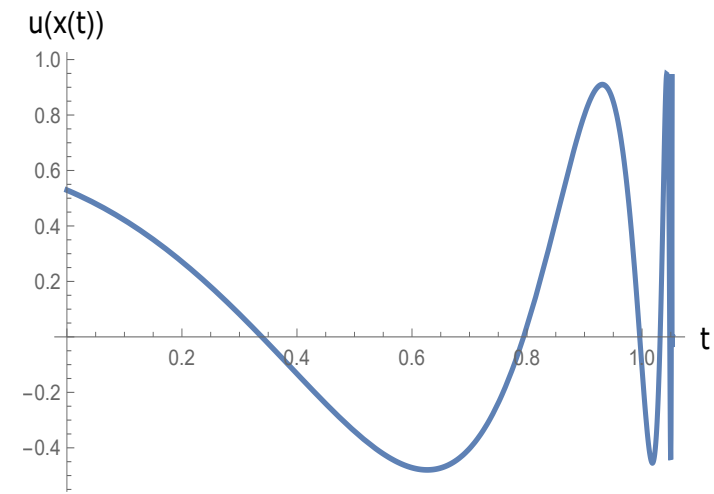

Fig. 5. The positional control $u(x(t))$.

The controllability function on the trajectory $\theta(x(t))$ is shown in Fig. 6 .

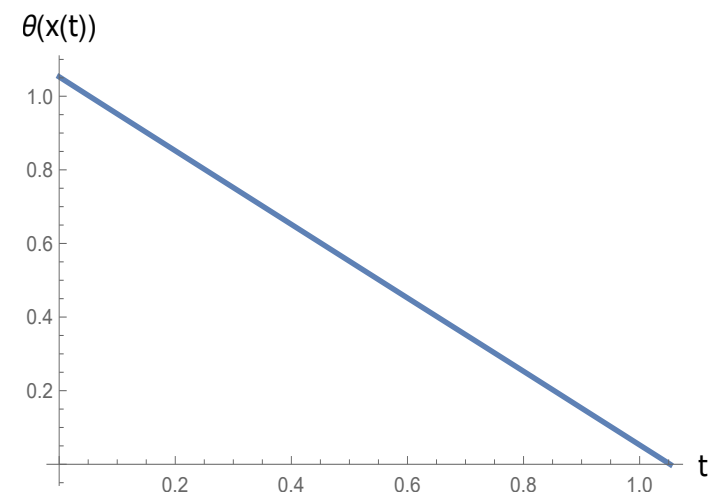

Fig. 6. The controllability function $\theta(x(t))$.

By using Wolfram Mathematica, we have calculated that the time of arriving from $x^{0}=(-0.05,-0.17,0.07)$ to the equilibrium point $\bar{x}$ is $T\left(x^{0}, \bar{x}\right)=$ 1.0528937566 and that $\left|x_{1}(T)\right| \leq 3.19427 * 10^{-11},\left|x_{2}(T)+\frac{1}{5}\right| \leq 6.57807 * 10^{-15}$ and $\left|x_{3}(T)-\frac{1}{5}\right| \leq 3.48898 * 10^{-8}$.

\section{Conclusion}

In this paper, a family of bounded finite-time stabilizing positional controls for the Rössler system is built. By using the controllability function method, which is 
a Lyapunov-type function, the finite time to reach the desired equilibrium point is estimated. This is obtained for an arbitrary given control bound and an adequate set $Q_{2}$ of initial conditions to achieve the control objective is computed. Let us note that this proposal may also be developed for any controlled system of the form:

$$
\dot{x}=f(x)+b u
$$

being $f(x)=A(x-\bar{x})+g(x), \bar{x}$ an equilibrium point of $f, A$ the jacobian matrix of $f$ evaluated in $\bar{x}$ and $g$ the corresponding nonlinear part of $f$ such that $\{A, b\}$ is completely controllable and $g$ is a lipschitzian function in a neighborhood of $\bar{x}$. We claim that the smaller the constant bound is, the more reduced is the set of initial conditions for which stabilization is guaranteed; see (14), (18) and (23). Moreover, the smaller the bound is, the longer is the time to arrive at the equilibrium point from the the same initial point; see (14), (18).

For the cases in which the Rössler system is chaotic, this technique may be implemented as a tool for control chaos. Indeed, if the equilibrium point is embedded in the strange attractor, a trajectory initiated in the basin of attraction of the attractor can reach the region $Q_{2}$ and by this moment, this finite-time control strategy can be activated, so, the equilibrium point will be reached in finite time. The use of finite-time stabilizing control for control chaos or for chaos synchronization is not new (see for example [26]). Hence, the introduction of this control strategy in these scenarios promises interesting future research.

Acknowledgement. The research of the first author is supported by CONACYT Project A1-S-31524 and CIC-UMSNH, Mexico.

ORCID ID

A.E. Choque-Rivero (iD https://orcid.org/0000-0003-0226-9612

G. A. González (iD https://orcid.org/0000-0002-9240-2132

E. Cruz Mullisaca (iD https://orcid.org/0000-0002-2044-6769

\section{REFERENCES}

1. K. T. Alligood, T. Sauer, J. A. Yorke. Chaos: An Introduction to Dynamical systems, Springer, - 1996. DOI: 10.1007/b97589.

2. J.-F. Chang, M.-L. Hung, Y.-S. Yang, T.-L. Liao, J.-J.Yan. Controlling chaos of the family of Rössler systems using sliding mode control, Chaos, Solitons and Fractals, - 2008. - V. 37. Issue 2. - P. 609-622. DOI: $10.1016 /$ j.chaos.2006.09.051

3. A. E. Choque-Rivero. The controllability function method for the synthesis problem of a nonlinear control system, International Review of Automatic Control, - 2008. - V. 1. no.4. - P. 441-445. 
4. A. E. Choque-Rivero. Solution of a Synthesis Problem of a Nonlinear Control System, Visnyk of V. N. Karazin Kharkiv National University. Ser. Mathematics, Applied Mathematics and Mechanics. - 2009. - 59(850). - P. 45-51. http://vestnik-math.univer.kharkov.ua/Vestnik-Khnu-850-2009-choq.pdf

5. A. E. Choque-Rivero, B. J. Gómez Orozco. Bounded finite-time stabilizing controls via orthogonal polynomials, 2018 IEEE International Autumn Meeting on Power, Electronics and Computing (ROPEC), Ixtapa, Mexico, - 2018. P. 1-4. DOI: 10.1109/ROPEC.2018.8661456.

6. A. E. Choque-Rivero, P. L. Cástulo Cruz. On Korobov's admissible maximum principle, 2016 IEEE International Autumn Meeting on Power, Electronics and Computing (ROPEC), Ixtapa, Mexico, - 2016. - P. 1-6. DOI: $10.1109 /$ ROPEC.2016.7830634.

7. A. E. Choque Rivero, V. I. Korobov, V. O. Skoryk. Controllability function as time of motion. I, Mat. Fiz. Anal. Geom., - 2004. - V. 11. no. 2. - P. 208-225 (in Russian); English translation in https://arxiv.org/abs/1509.05127.

8. A. E. Choque Rivero, V. I. Korobov, V. O. Skoryk. Controllability function as time of motion. II, Mat. Fiz. Anal. Geom., - 2004. - V. 11. no. 3. - P. 341-354. (in Russian).

9. A. E. Choque-Rivero, F. Ornelas-Tellez. Bounded finite-time stabilization of the prey-predator model via Korobov's controllability function, accepted to appear in Izv. Sarat. Univ. (N.S.) Ser. Mat. Mekh. Inform. - 2020.

10. V. Dobrushkin. Mathematica Tutorial for the Second Course in Differential Equations. Part III: Rossler attractor. 2015. http://www.cfm.brown.edu/people/dobrush/am34/Mathematica/ch3/rossler. html

11. B. C. Kuo. Sistemas de control automático (7ma. Edición). 1996. Prentice Hall Hispanoamericana, S. A., Mexiko, 930 p. (in Spanish) https://dademuchconnection.files.wordpress.com/2017/07/sistemas-de-controlautomatico-benjamin-c-kuo.pdf.

12. X. Liao, P. Yu. Chaos control for the family of Rössler systems using feedback controllers, Chaos Solitons \& Fractals, - 2006. - 29(1). - P. 91-107. DOI: $10.1016 /$ j.chaos.2004.12.046.

13. D. G. Luenberger. Observers for multivariable systems, IEEE Trans. Automat. Contr., V. AC-11. no. 2. - 1966. - P. 190-197. DOI: 10.1109/TAC.1966.1098323.

14. V. I. Korobov. A general approach to the solution of the problem of synthesizing bounded controls in a control problem, Mat. Sb. - 1979. - V. 109(151) 
no. 4(8). - P. 582-606 (in Russian); Engls translation: Math. USSR Sb. 37 (1980), No. 4, 535-557. DOI: 10.1070/SM1980v037n04ABEH002094.

15. V. I. Korobov. Controllability function method. 2007. NITS, Inst. Comp. Research, M-Ighevsk

16. V. I. Korobov, G. M. Sklyar. Methods for constructing of positional controls and an admissible maximum principle, Differ. Uravn., - 1990. - 26(11). P. 1914-1924.

17. V. I. Korobov, V. O. Skoryk. Construction of restricted controls for a nonequilibrium point in global sense, Vietnam Journal of Mathematics. - 2015. 43(2). - P. 459-469. DOI: 10.1007/s10013-015-0132-4.

18. H. F. Marj, R. Asgharian, N. Pariz. Controlling chaotic Rossler system via synchronization, using bifurcation parameter to choose desirable periodic orbit, Journal of Applied Sciences. - 2009. - 9(8). - P. 1450-1457. DOI: $10.3923 /$ jas.2009.1450.1457.

19. A. Ovseevich. A local feedback control bringing a linear system to equilibrium, J. Optim. Theory Appl. - 2015. - V. 165 no. 2. - P. 532-544. DOI: $10.1007 / \mathrm{s} 10957-014-0636-1$.

20. A. Polyakov, D. Efimov and W. Perruquetti. Finite-time stabilization using implicit Lyapunov function technique, Proceedings of the 9th IFAC Symposium "Nonlinear Control Systems"(NOLCOS), Toulouse, France - 2013. - 46(23) P. 140-145. <hal-00844386>. DOI: 10.3182/20130904-3-FR-2041.00043.

21. A. S. Poznyak, A. Y. Polyakov, V. V. Strygin. Analysis of finite-time convergence by the method of Lyapunov functions in systems with second-order sliding modes, J. Appl. Math. Mech, - 2011. - V. 75. Issue 3. - P. 289-303. DOI: 10.1016/j.jappmathmech.2011.07.006.

22. M. Radford. A study of the Rössler system. 2007. School of Physics Jawja Institute of Technology, 12 p. http://www.chaosbook.org/projects/Radford/radford.pdf.

23. M. Rafikov, J. M. Balthazar. On an optimal control design for Rössler system, Physics Letters A, - 2004. - Issue 3-4. V. 333. - P. 241-245. DOI: $10.1016 /$ j.physleta.2004.10.032.

24. M. Rafikov, J. M. Balthazar. On control and synchronization in chaotic and hyperchaotic systems via linear feedback control, Communications in Nonlinear Science and Numerical Simulation, - 2008. - Issue 7. V. 13. - P. 1246-1255. DOI: 10.1016/j.cnsns.2006.12.011.

25. O. E. Rössler. An equation for continuous chaos, Physics Letters A, - 1976. - Issue 5. V. 57. - P. 397-398. DOI: 10.1016/0375-9601(76)90101-8. 
26. H. Wang, Z. Han, Q. Xie, W. Zhang. Finite-time chaos synchronization of unified chaotic system with uncertain parameters, Commun Nonlinear Sci Numer Simulat, - 2009. - Issue 5. V. 14. - P. 2239-2247. DOI: $10.1016 /$ j.cnsns.2008.04.015.

27. T. H. Yeap, N. U. Ahmed. Feedback control of chaotic systems, Dynamics and Control. - 1994. - V. 4. Issue 1. - P. 97-114. DOI: 10.1007/BF02115741.

Чоке-Ріверо А. Е., Гонзалес Грасіела А., Круз Муллісака Е. Метод функції керованості Коробова, застосований до стабілізації системи Росслера за обмежений час за допомогою обмежених керувань. Система Росслера стала однією з референтних хаотичних систем. Ї̈̈ новизна при введенні, була в тому, що вона демонструє хаотичний атрактор, породжений більш простим набором нелінійних диференціальних рівнянь, ніж система Лоренца. Ця система за певних значень іiі триплета параметрів демонструє хаотичну поведінку. Питання керування системою Росслера шляхом стабілізації однієї з тї нестійких точок рівноваги раніше розглядалося в літературі. У цій роботі запропоновано керування системою Росслера на основі задачі синтезу. Для заданої системи та однієї з тї точок рівноваги, задача синтезу полягає у побудові обмеженого позиційного керування таким чином, що для будь-якого $x^{0}$, що належить певному околу точки рівноваги, траєкторія $x(t)$, що починається в $x^{0}$, дістається до цієї точки рівноваги за скінченний час. А саме, з використанням методу В. І. Коробова, який також називають методом функції керованості, пропонується сім'я обмежених позиційних керувань, які розв'язують задачу синтезу для системи Росслера. В основному ми використовуємо два компоненти. Перший стосується загальної теорії функції керованості. Другий компонент - це сім'я обмежених позиційних керувань, яка будується в цій роботі. На відміну від попередніх робіт щодо стабілізації за скінчений час, ми пропонуємо явну сім'ю обмежених керувань, побудовану з урахуванням лише нелінійності системи Росслеpa, яка $\epsilon$ квадратичною функцією. За допомогою методу функції керованості, яка $\epsilon$ функцією типу Ляпунова, оцінюється скінченний час, потрібний для досягнення бажаної точки рівноваги. Цю оцінку отримано для довільно заданої межі керування,а також наведено відповідну множину початкових умов для досягнення мети керування. Цей підхід може бути також розвинутий для будь-якої керованої системи, лінійна частина якої є повністю керованою, а її відповідна нелінійна частина ліпшицевою функцією в околі точки рівноваги. У свою чергу, ця техніка може бути реалізована як інструмент керування хаосом.

Ключові слова: Система Росслера; функція керованості Коробова; обмежене керування; стабілізація за скінченний час.

A. E. Choque-Rivero, Graciela A. González, E. Cruz Mullisaca. Korobov's controllability function method applied to finite-time stabilization of the Rössler system via bounded controls. Rössler system has become one of the reference chaotic systems. Its novelty when introduced, being that exhibits a chaotic attractor generated by a simpler set of nonlinear differential equations than Lorenz system. It develops chaotic behaviour for certain values of its parameter triplet. The issue of controlling Rössler system by stabilizing one of its unstable equilibrium points has been previously dealt with in the literature. In this work, control of the Rössler system is stated by considering the synthesis problem. Given a system and one of its equilibrium points, the synthesis problem consists in constructing a bounded positional control such that for any $x^{0}$ belonging to a certain neighborhood of the equilibrium point, the trajectory $x(t)$ initi- 
ated in $x^{0}$ arrives at this equilibrium point in finite time. Namely, by using V. I. Korobov's method, also called the controllability function method, a family of bounded positional controls that solve the synthesis problem for the Rössler system is proposed. We mainly use two ingredients. The first one concerns the general theory of the controllability function The second ingredient is a family of bounded positional controls that was obtained in. Different from previous works on finite-time stabilization we propose an explicit family of bounded controls constructed by taking into account the only nonlinearity of the Rössler system, which is a quadratic function. By using the controllability function method, which is a Lyapunov-type function, the finite time to reach the desired equilibrium point is estimated. This is obtained for an arbitrary given control bound and an adequate set of initial conditions to achieve the control objective is computed. This proposal may also be developed for any controlled system for which its linear part is completely controllable and its corresponding nonlinear part is a lipschitzian function in a neighborhood of the equilibrium point. In turn, this technique may be implemented as a tool for control chaos.

Keywords: Rössler system; Korobov's controllability function; bounded control; finite time stabilization.

Article history: Received: 15 February 2020; Final form: 15 May 2020;

Accepted: 18 May 2020. 